Short Communication

\title{
Preparation of Graphene-Cement Paste Anode for Chloride Extraction from Marine Reinforced Concrete Structures
}

\author{
Li-Cai Zhao ${ }^{*}$ and Shi-Shuenn Chen \\ Department of Civil and Construction Engineering, National Taiwan University of Science and \\ Technology, No.43, Section 4, Keelung Road, Taipei 10607, Taiwan \\ *E-mail: D10305810@mail.ntust.edu.tw
}

doi: $10.20964 / 2016.11 .15$

Received: 2 August 2016 / Accepted: 6 September 2016 / Published: 10 October 2016

\begin{abstract}
Electrochemical chloride extraction (ECE), a technology for the rehabilitation of chloridecontaminated concrete, has attracted widespread attention. The performance of the ECE method towards marine reinforced concrete was studied with the graphene-cement paste as anode and artificial sea-water as electrolyte. The efficiency of removing chloride obtained with graphene-cement anode was higher than that obtained with a conventional $\mathrm{Ti}-\mathrm{RuO}_{2}$ mesh anode. With the usage of the graphene-cement anode, the chloride extraction process was found to be more effective for the surface area. In addition, the performance of ECE process was also investigated by altering various parameters such as moistening frequency and current density. The results demonstrated that every $12 \mathrm{~h}$ drip moistening system was necessary in order to maintain the constant humidity, and further constant performance.
\end{abstract}

Keywords: Electrochemical chloride extraction; Graphene-cement; Moistening; $\mathrm{Ti}-\mathrm{RuO}_{2}$;

\section{$\underline{\text { FULL TEXT }}$}

(C) 2016 The Authors. Published by ESG (www.electrochemsci.org). This article is an open access article distributed under the terms and conditions of the Creative Commons Attribution license (http://creativecommons.org/licenses/by/4.0/). 